\title{
下腹神経の実験生理学的研究
}

\author{
横浜市立大学医学部泌尿器科教室 \\ 横浜市立大学医学部生理学教室 井田 時 雄 \\ (指導 : 皇山一平教授)
}

\section{EXPERIMENTAL AND PHYSIOLOGICAL STUDIES OF THE HYPOGASTRIC NERVE}

\author{
Tokio Ida \\ From the Department of Urology, Yokonama University School of Medicine, Yokohama \\ (Chief: Prof A. Harada) \\ From the Department of Physiology, Yokohama University School of Medicine, Yokohoma
}

(Director: Prof. I. Hatakeyama)

The role of the hypogastric nerves in the activity of cat's bladder was studied by means of nerve stimulation as well as exploration of the pattern of afferent impulses obtained from the same nerve.

The results were as follows:

1) Section of the hypogastric nerve resulted in lengthening of the period of spontaneous rhythmic contraction of the bladder in case of high intravesical pressure, while shortening of the period in case of low intravesical pressure.

2) Stimulation given to the peripheral cut-end of the hypogastric nerve developed a brief contraction of the bladder which was followed by a marked relaxation. These characteristic phenomenon did not occur when the pelvic nerve and/or the inferior mesenteric ganglion was cut prior to the examination.

3) The effect of stimulation of the peripheral cut-end showed no significant difference as compared with the effect of the central cut-end of the nerve.

4) Autonomic reflex changes such as a rise of blood pressure and a change of respiratory pattern were obtained when stimulation was applied to the central cut-end. Such change, however, was not seen when the peripheral cut-end was stimulated.

5) Hypogastric afferent impulses evoked by increase of intravesical pressure were considered to be two different groups. The first group comprised of impulses which were supposed to carry painful sensation without bearing any relation to mechanism of micturition. This type of impulses was observed only when the bladder was distended maximally and its adaptation was uaually very slow. The second group comparised of impulses which were induced along with gradual rise of the intravesical pressure.

Summarising the above results of experiments, it may be concluded that:

1) The hypogastric nerve appears to inhibit the activity of the bladder;

2) Dr. Sokownin's finding is not acceptable. He clearly stated that there was an axon reflex by way of the inferior mesenteric ganglion;

3) The fact that centripetal stimulation of the hypogastric nerve brings about autonomic reflex changes suggests that the bladder activity, more specifically, its relaxation seems to be more closely related to the reflex micturition center located in the medulla oblongata rather than the influence of the hypogastric nerve;

4) Afferent impulses passing through the hypogastric nerve seems to be the evidence of transmission of the painful sensation. It may well be understood that the change of the intravesical pressure is conducted through the same pathway. 


\section{1. 緒 垔}

古来排永機構に関し幾多の研究がなされ、膀胱文配神 経並びに排尿中樞々膀胱機能々の関係な, 漸次明ら心に されてきたが，前者の作用機序先仔紐に検討するに未心 不明の点が多い。

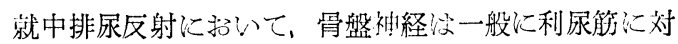

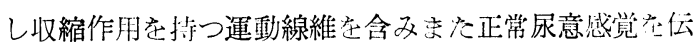
える求心路であるといわれている。一方下腹神経流，利 尿筋に対しては抑制的に働き，桨た膀胱よりの膨湍愁， 疼痛, 温度感覚等の求心路とされているが, 排尿反射に 対しては補助的な役割を演ずるに過ぎ好いわれ，この 作用機序について検討されるべき余地が残されている。

この神経の切断は, 膀胱運動或牥它の緊張化僅かの変 化をもたらすのみで(Mosso and Pellacani ${ }^{29)}$, Elliott ${ }^{7)}$, Barrington $^{3)}$, Dennigige ${ }^{32)}$ Langworthy, Reeves and Tauber ${ }^{24)}$, 中野 ${ }^{30)}$ ), 遠心路の刺激効果の㪕告もまちま亏だ ある. (Barrington ${ }^{4) 5}$, Elliott ${ }^{7)}$, Courtade and Guyon 6), Gaskell ${ }^{12)}$, Edmund and Roth ${ }^{49)}$, Scabadasch ${ }^{37)}$, MacDonald and $\mathrm{McCrea}^{27)}, \mathrm{McCaughan}^{28)}$, Stewart ${ }^{43)}$, Mellanby and Pratt ${ }^{33}$, Wang and Harrison ${ }^{45}$, Langworth, Kolb and Lewis ${ }^{25)}$, Alpers ${ }^{2}$, Kuntz and Saccomano ${ }^{17)}$, Hegre and Ingersol1 ${ }^{13144)}$ またCの神経を求心 路とし，利尿筋運動を効果とする反射についての報告主 軸索反射である (Langley et $\mathrm{al}^{23)}$ ) という意見がでる 程で，久留等の系統的研究にもかかわらず定見とず゙を もの岎確立されていない。

下股神経学求心路と与る反射の効果に利尿筋運動に刘 ナる反応がみられるが，血圧呼吸等の自律性機能仗没汸 学影響も少なくないととが若干の研究によつて報告され ている. 下腹神経の生理学的意義は多面的で, その一面i から本質を把握すること㹥困難といわね忟ならない，菑 者はこの点にかんがみ, 刺激生理学的並び電気生理学 的手法を用いる系統的研究によつて, この神経の生理:学: 的性質を各面より探り以下に还べる成果を得た。

\section{2. 実験方法}

実験動物としては, 体亚 2.0〜 3.0kgの猫を使川し た. 体重 $1 \mathrm{~kg}$ たり $1 \mathrm{~g} の$ urethaneの筋肉注射で森醉 した動物を背位に固定し，劍状突起より取骨結合に至る 腹部正中切開で腹腔内に達し, 膀胱，その支配神経並び に血管及び尿道を露出した。ついで晹管を外側に圧排

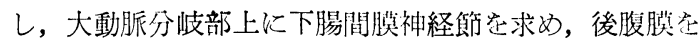
開き該神経節より左右 2 本に分岐少る下腹神経を胃出 し，周囲組織より充分に分離した。ついで骨盤神経を福

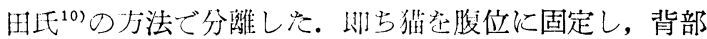
正中切開を加え更に尾根部灭び大腿部にわたり皮膚を剥 離し，大腎筋及歹び中慰筋，下股筋を露出，乙れらを切断 し視野に現れた腸骨櫛を骨鉜子で除き，ついでその下に ある梨状筇をも切除し，兰ら江大腿の方向に走る坐霄神 経を血管と其に中樞近くで結楒切断し，その直下で坐骨

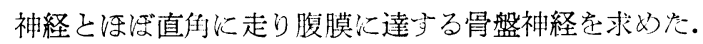

膀胱頚部より $4 \sim 5 \mathrm{~cm}$ 下端で尿道に切開を加 5 No. 6のネラトン氏カテーテルを插入し，次のよう な方法で膀胱運動を记録観察した。尿道に扱入したカテ 一テルは，三方活栓军経て一方はU字管圧力計に，他方 は系のcompliance 学大きく少るための空気溜め(reservoir）を介して電気圧力計化つな゙る。膀胱は加温され た生理的食塩水により水銀王力計及び reservoir と連結 され, 膀胱内压と膀胱容積変動の測定を行う. reservoir 内の僅かな空気圧変動が容積変動を示すものであるが, との圧老 capacitance manometer によつて記録測定し た(第 I 図).膀胱容積10ccの減少怡約 $12 \mathrm{~mm} H \mathrm{Hg}$ の reservoir

第 1 図实験装置

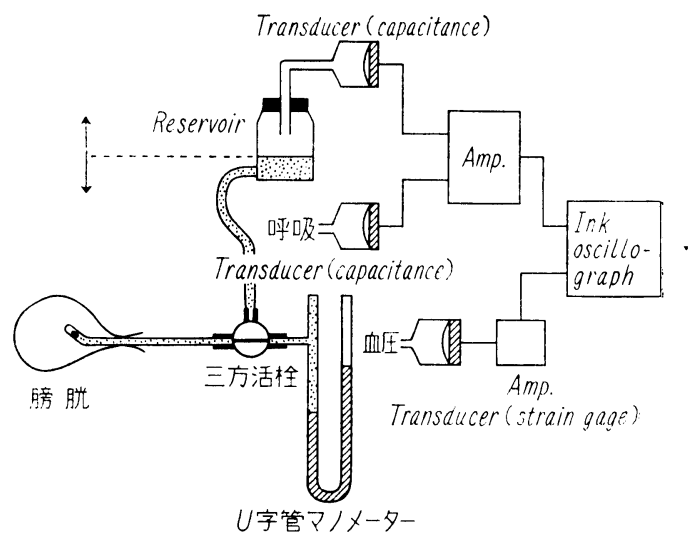

内压変化をひき起す。

呼吸曲線, 呼吸流速曲線㳉至机ぞれ蛇管式 pneumograph 双び抵抗型 pneumotachograph と capacitance manometer を用いて記録した。

動脈血圧は陑動脈から strain gauge を transducer する電気血圧計, 直流增巾器を経てインク書きオッシロ グラフにより, 前述の膀胱溶積变動, 呼吸曲線及び呼吸 流速曲線と同時描記した。

下腹䄄経活動電位の録にあたつては，前述したよう な万法で膀胱容積变動を測定し, その変化分を留気量に

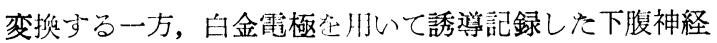


の活動電位と共に 2 要素のブラウン管オッシログラフの それぞれのチヤンネルに雨入して同時記録した。この際 カテーテル突介しての点滴注入により，急激岕るいは緩 除纪膀胱学伸展し膀胱太圧竟变動させた。（第2図）下 腹神経の活動電位の記録に際し，下腹神経空下腸間膜神 経節の末梢端約 $1 \mathrm{~cm}$ ととろで切断し，Adrian \& Bro$\mathrm{nk}^{1)}$ の方法堂用いて線維省少数の群比分離した.

神経の電気的刺激梳万能型電子管刺激裝置によるくり 返し矩型波パルスにより行つた。

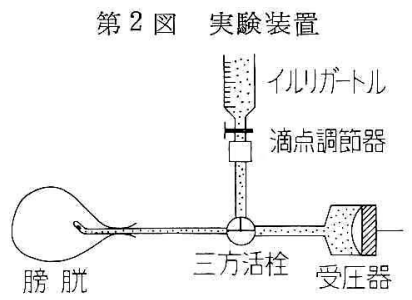

\section{3. 実験結果}

実験况下腹神経の切断, 並び飞刺激時の膀腅容 積变 動，呼吸並びに血圧の受ける影響と同神経の活動電位と 膀胱内圧との関係の観祭という順序で行われた。 この順 序に従つて記述古進めることをする。

1）下腹神経の切断

一定範囲の膀胱内圧下飞挄いて, 律動的容積変動がみ られ\%。との律動的变動の振幅は，膀腃内圧 $15 \mathrm{~mm} H \mathrm{Ig}$ で約 $3.5 \mathrm{cc}$ あ゙り, 膀胱内圧 $5 \mathrm{mmHg}$ 以下では, 律動性変動洂 認められず，30 mmHg上で济極めて不安定，不規則乞な 尚.

\section{i）浐胱支配神経無処置群}

膀胱支配神経に何等の操作も加えずに膀胱内压学 4 段 階に分けて膀胱の律動性变動学観察し\% (第 3 図).

律動性変動の周期焒，内圧の増加と共に減少し，振幅

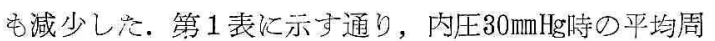

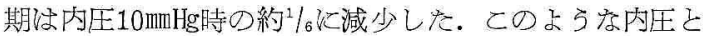
周期との関係は全例にみとめられた。

ii）下腹神経切断群

下腹神経一側切断及び両側切断の膀胱律動性変動に及

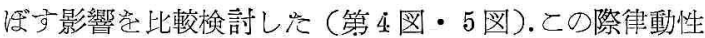

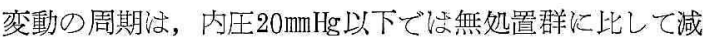

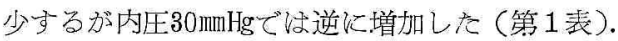

下腹神経切断後, 律動性变動の規則性洨比較的々く保 たれ，正常膀胱群が内圧 $30 \mathrm{~mm} H \mathrm{Hg} そ$ その律動性が乱される のに対して切断群では尚保持されている.

2）下腹神経末梢端刺激

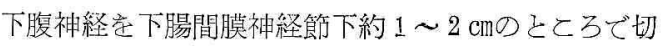
斷し，その末梢端㧈よび中樞端の電昰的刺激它行なつて 膀腅容積变動，血圧改び呼吸飞對守る效果を祫討した。 刺激洂20c/s の短形波（愊 $2 \mathrm{msec}$ ） 学用いた。

上述のように膀胱容積柱自發的に律動性变動走示して

第 1 表 膀脱の律動的容積変動の周期と内王

\begin{tabular}{|c|c|c|c|c|}
\hline 内珐 & $5 \mathrm{~mm} H g$ & $10 \mathrm{~mm} H \mathrm{Hg}$ & $20 \mathrm{~mm} \mathrm{Hg}$ & $30 \mathrm{~mm} H g$ \\
\hline 正常膀胱 & $(\overline{\mathrm{sec}})$ & $\begin{array}{c}5.7 \\
\text { (sec.) }\end{array}$ & $\begin{array}{c}1.8 \\
(\mathrm{sec} .)\end{array}$ & $\begin{array}{c}0.9 \\
\text { (sec.) }\end{array}$ \\
\hline $\begin{array}{l}\text { 一側下腹 } \\
\text { 神経切断 }\end{array}$ & 3.2 & 2.7 & 1.5 & 1.3 \\
\hline $\begin{array}{l}\text { 両側下腹 } \\
\text { 神経切断 }\end{array}$ & 5.0 & 2.4 & 1.4 & 1.3 \\
\hline
\end{tabular}

第 3 図 支配神経無処置の猫の膀胱容積変動

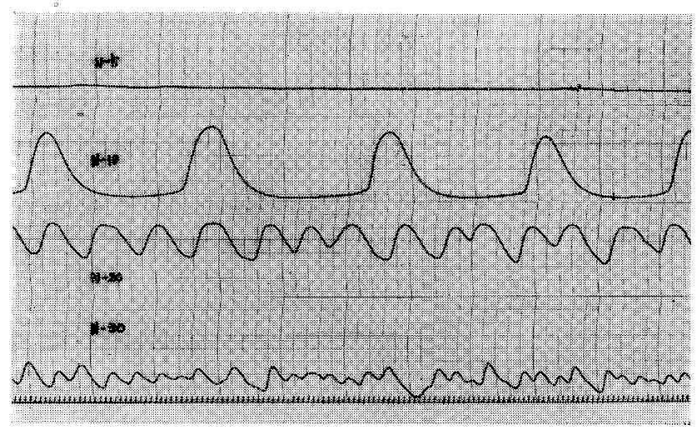

上より膀胱内压 $5 \mathrm{mmHg} ， 10 \mathrm{~mm} H \mathrm{Hg}, 20 \mathrm{mmHg}, 30 \mathrm{~mm} H \mathrm{Hg}$. 時標 1 秒

第 4 図片側下腹神経切断時の猫の膀脱容積変動

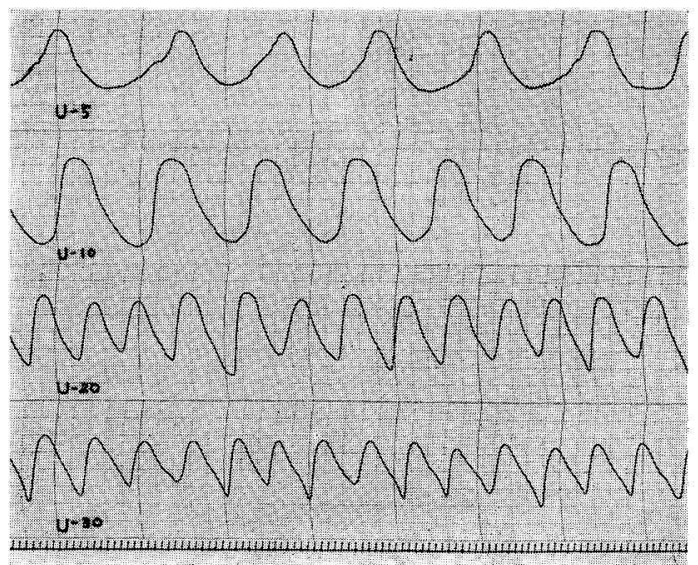

上より膀腃内圧 $5 \mathrm{mmHg}, 10 \mathrm{~mm} H \mathrm{gg}, 20 \mathrm{~mm} H \mathrm{Hg}, 30 \mathrm{~mm} H$. 時標 1 秒 
第 5 図 両側下腹神経切断時の猫の膀胱容積变動

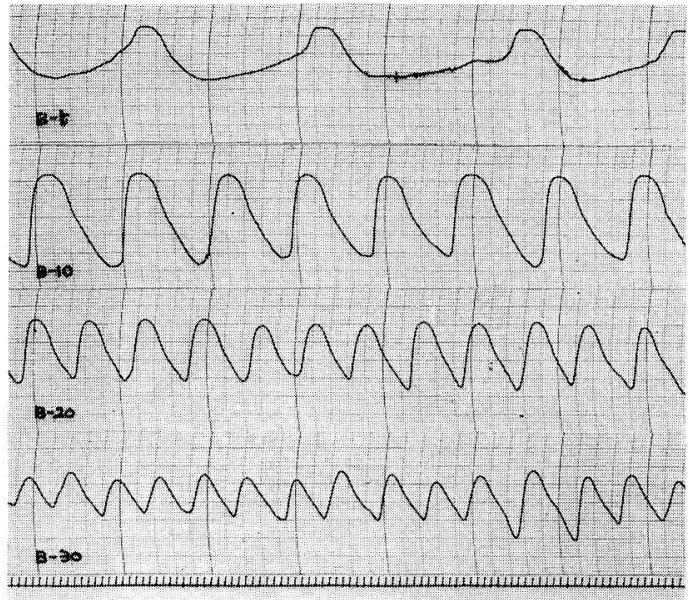

上より膀脱内圧 $5 \mathrm{~mm} H \mathrm{Hg}, 10 \mathrm{mmHg}, 20 \mathrm{~mm} H \mathrm{Hg}, 30 \mathrm{mmHg}$. 時標 1 秒

第 6 図下腹神 経末梢端刺激

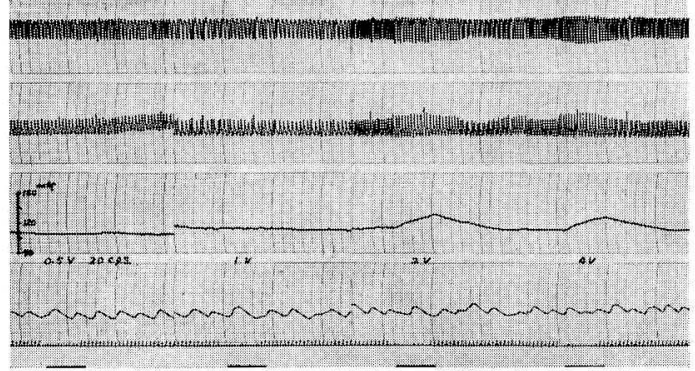

oncom

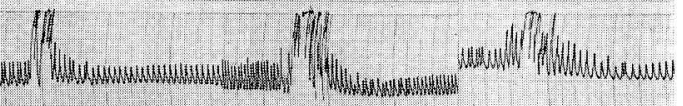

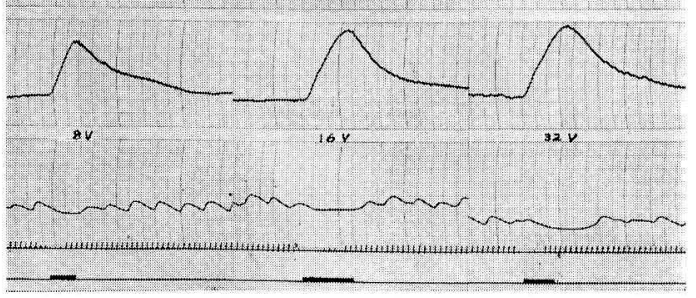

上より呼吸流速曲線, 呼吸曲線, 血圧, 膀胱容積 (上に減少), 時標 ( 1 秒). 刺激記号

䧛胱内圧 $20 \mathrm{mmHg}$ 一定, 刺激 $20 \mathrm{c} / \mathrm{s}$ の短形波パルス。
第 $7 \mathrm{a}$ 図

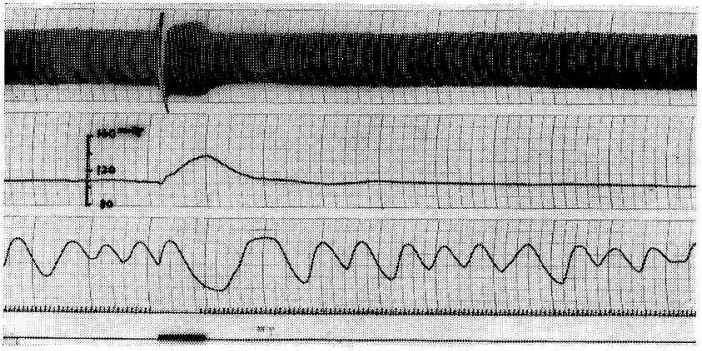

第 $7 \mathrm{~b}$ 図

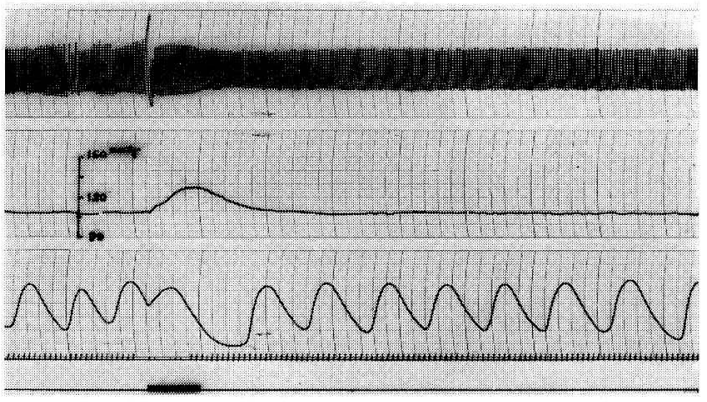

第 $7 \mathrm{c}$ 図

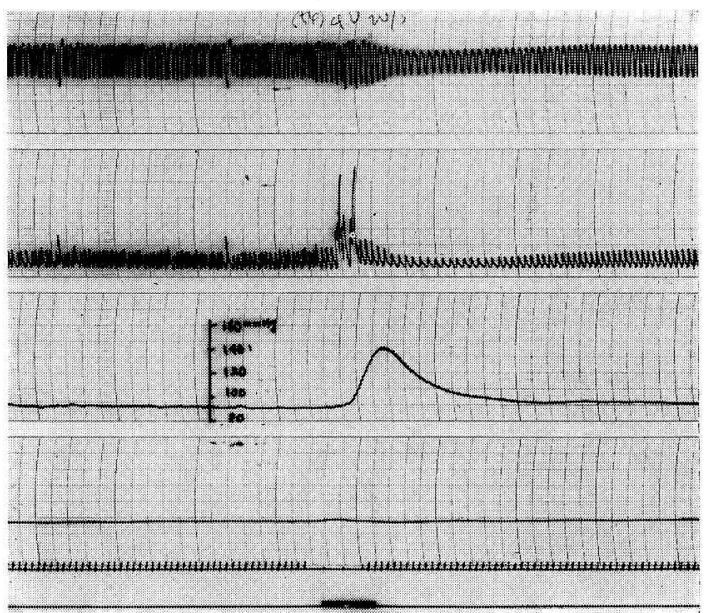

下腹神経中枢端刺激

上より呼吸流速曲線，血圧，膀胱容積 (上飞減少), 時標 ( 1 秒), 刺激記号, 膀胱内圧 $20 \mathrm{mmHg}$ 一定, 刺激 $20 \mathrm{c} / \mathrm{s}$ の短形波パルス.

第 $7 \mathrm{a}$ 図：片側下腹神経切断 第 $7 \mathrm{~b}$ 図：两側下腹神経切断 第 $7 \mathrm{c}$ 図: 両側骨盤神経切断 
いるので,刺激效果の判定ね簡単ではない.しかし規則的 な律動性を示している場合に法その規則性の乱れで効果 のあつたととが判然と解る．従つて刺激効果が膀胱佂對 し拡張的である收收縮的であるかの判定は，平均容積の 増減とい点に注目して行なうことになる。刺激効果の大 きさは刺激条件によつて变るが，その効果の本質は同じ であつた，著者の用いた刺激条件では血圧已呼吸化對卞 る效果は認められなかったが，膀胱容積变動に浫収縮的

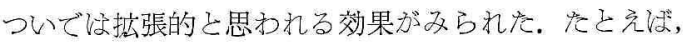
自発性の掘張の進えでいる時に刺激が行なわれると，そ

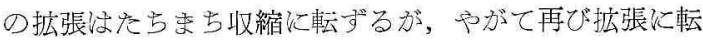
じ自発的桩張の最大值よりむ更に拡張するに至る(第6 図)とのことほ刺激效果の 2 相性意味している.

\section{3）下腹神経中樞端刺激}

下腹神経切断中樞端定刺激する己䁤胱容積だけでな

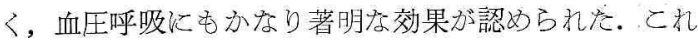
らの刺激効果の大きさ济一般飞刺激強度や刺激頉度の増 加と共に大きくなるが, 著者の行なつた実験範团では去 の定珄的な内容は刺激頻度や刺激強度によつて变ること がなかった。

膀胱容積に對する効果な一過性の減少に続く增大であ る点で前述の未梢端刺激效果に類似しているが（第 6 図), その容積娍少效果ほ概して目立たず，完全に消失し て純粹な容積増加効果しか認められ妨ことがあつた ( 7 a図). また刺激期間中は律動性変動の消失も文ら礼た。

血圧飞対しては純粹な上昇効果学示した. 刺激条件飞 よつてね50mm Hgkも及ぶ著明な昇圧がひき起された。呼 吸に対しては，頻度の娍少と共に振幅の増大，従つて呼 吸気量の増大をひき起した。

このような刺激効果は片側の下腹神経が健在であるか 否か以は無関係であつて，両側下腹神経切断後む全く変 ら奴効果が見られた（第７b図）。しかし両側骨盤神経圭 切断する己膀胱に刘する効果は極めて小さくなるか，市 るい消失するかに至る，効果があつた場合，その傾向 は骨盤神経残存の場合と同じで一過性の容積减少に続く 增加であつた。 ところが血压及び呼吸に対ずる効果な本 神経切断前と全く同様であつた (第7 c 図).

4）膀胱伸展時《みら机る下腹神経求心性インパルス 膀胱内一 $37^{\circ} \mathrm{C}$ 亿加温した生理的食塩水を注入し, 下腹 神経切断末梢端より得られる求心性インパルスと膀胼内 圧との関係定検討した。

下腹神経切断後膀胱内一点滴注入学綏除に行なうと, 膀胱内代は次第に上昇する。膀胱内压が低い時にはイン
第 8 図 膀胱伸展時の下腹神経求心性インパルス。

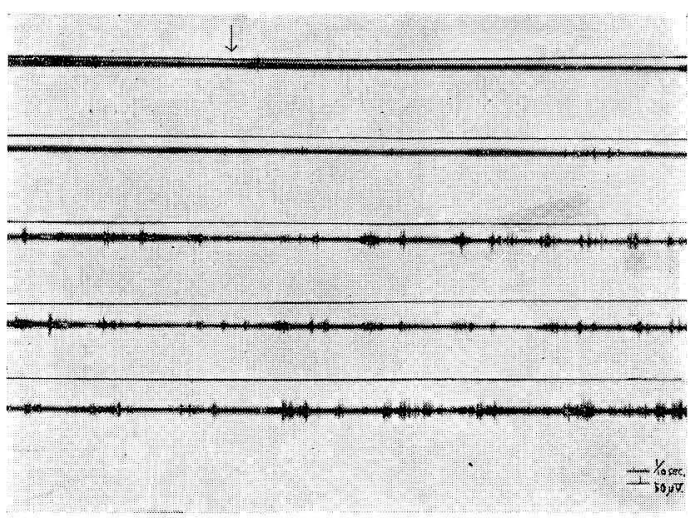

上 : 膀睄内王, 下 $:$ 下腹神経放電

矢印の点より䧛胱内点滴注入開始. 膀脱内王 $0 \rightarrow$ $50 \mathrm{~mm} \mathrm{Hg}$

パルスは出現しないが, 膀胱内圧 $10 \mathrm{~mm} H \mathrm{~g}$ 以上飞なるとま

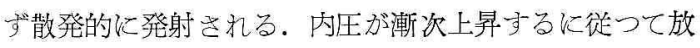
電の頻度は增すが，連続的ではなく間欠的であつて休止 期孛有するインパルス群をして出現する.しかし内压が 上昇するに従つて休止期炇淢少し，添とんど連続的な discharge となる(第 8 図).

膀胱内一の点滴注入学早急儿行ない，急激に膀胱内压 を上昇させると第 9 园に示すどしく内压の上昇と同時に 一過性のインパルス群が現れる.内圧の上昇学維持する そ, し涩らくの沈默期置いて間久的な放電群が生ず る. 内压の急激な下降の際にも過渡的にインパルス群が 現れるが，下降後は全くインパルスの放電は行われな い.

第 9 図 膀胱伸展時の下腹神経求心性インパルス。

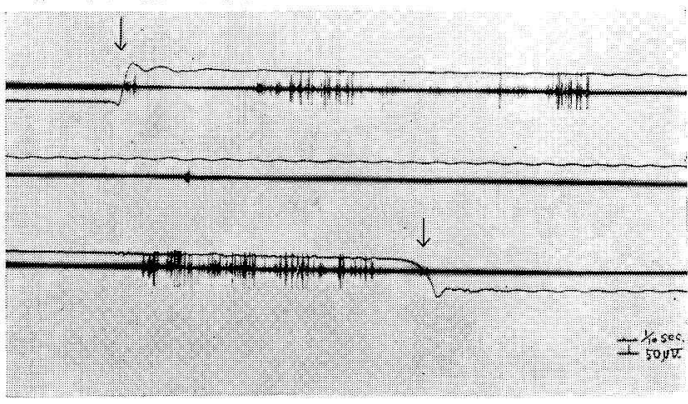

上：䧛腅内圧, 下 : 下腹神経放電 矢印の点で膀胱内点滴注入開始及び排液. 内圧 $0 \rightarrow 50 \mathrm{~mm} H \mathrm{Hg}$

5）下腹神経末梢端の電気刺激と求心性インパルスと の関連 
下腹神経の切断末梢端刺激により，膀胱は一過性の収 縮とそれに引続く弛緩をみるとと湔前述したところであ る. との際下腹神経の求心性インパルス注どのようにな つているのであろうか. 第10図に示与゙うに下腹神経イ ンパルス注自発的な膀胱容積減少の際に放電頻度导增加 していると流いず，との例ではさしろ減少している程 であるが，刺激によつて生じた容積減少の㭙に法明らか に放電が著しくなる。しかし刺激中であつても容積が増 加するに従つて放電峙弱委り休止期もみられるようにな つた. 容積増大效果の続く間, 放電頻度は減少ずるが容 積が再び減少し，その律動性変動が元のレ心゙ルに回復す るにつれて再び放電頻度ね増加した。

第10図下腹神経末梢端刺激時の求心性インパルス。

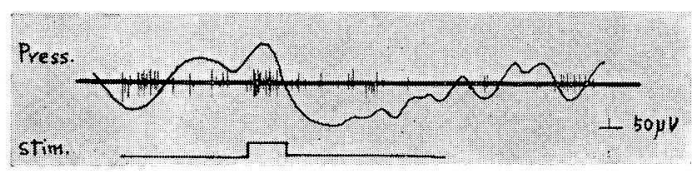

上より膀脱容積, 下腹神経放電, 刺激記号. 刺激 20 c/s の矩形波パルス, 刺激時間 $10 \mathrm{sec}$, 膀脱内圧 20 m m $\mathrm{Hg}$

\section{4. 考 察}

膀胱容積が自発的汇律動性变動学呈するとと䄈, よく 知引れた事実である。一般に平滑筋は律動的な自発性收 縮党起し易々，自発的収縮密生じせしぬ状態で長く観 察記録するととの堪だ困難な場合がむしろ多い，それ故 平滑筋学構成要素として持つ膀胱がこのよらな性質を示 すととは当然といわね济ならない，本論文は，との律動 的收縮の解析を目的とするるるのではなく，またその機構 を明らかにし得るだけの積極的な实験它行なつていない ので，艺の諸性質についてとかくの論議をするととは避 けたい.

下腹神経の存否は膀胱の律動的容積変動の周期に，い かなる影響麦もたらすものであるらか. 周知のでとく， 下腹神経の末梢運動路ししての作用は，利尿笳汶対して は抑制的飞働く，下腹神経の切断後，膀胱容積の減少が びき起されるととからも，下腹神経が副交感神経の作用 と拮抗してその作用定弱めるものと推测されている ${ }^{24)}$.

膀胱の律動的容積变動の周期が、低内压㭙に膀胱支配 神経無処置群と比較して, 下腹神経切断群にあつてね短 縮が著明であつた。（算1表）またどく低い内圧で現れ 難い律動的収縮が神経切断により発現する。とれは下腹 神経の利尿筋飞対する抑制作用が，神経切断认なり失な われ利尿筋の緊張が高まつた結果，その自発性收縮が昂
進したものとして理解できる. 平滑筋にはとのような一 般的性質がある。筋の収縮速度は㖘力之共汇娍少主るか ら (A.V. Hill の荷重已短縮速度に関与る法則による) 周期の短かい程振幅も減少する。

一方高内圧特の容積変動の周期にば，低内圧封のそれ と比较して，下腹神経の存否に拘らず認むべき差がみら

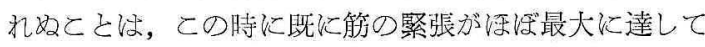
いるためと考光られる. 高内圧時には物論利尿筋に加わ る張力が増加するが，それに伴い筋の能動的緊張が増し その結果自動性收綃の周期が短衣くなるとと筫 1 表に 示す通りである．緊㖘が最大に近くなると，筋張力の増

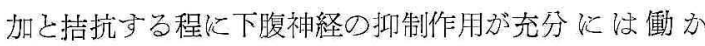
ず, 從つて下腹神経があるうとなかららと律動的容積変 動の周期脑，深とえど同じ值学保つと思われる.

一方とのような膀腅の律動的容積変動は, 骨盤神経切 断後消失する. Scherrington ${ }^{40}$ は, 骨盤神経切断後の律 動性の消失は多く一時的で, 時間の経過さ共に再び出現 するが，もはや規則的ではなくなるのであつて骨盤神経 切断後の利尿筋の緊張の低下が原因である己結論してい る. 一方 Pratt and Mallenby ${ }^{33}$ は, 骨盤神経切断後, adrenaline 並びに acethylcholine 飞対可る膀胱反応も 失われるととから，もともとしのような律動性変動证骨 盤神経等学介する反射現象であると結論している。しか し内圧変化の影響己下腹神経切断の效果学考慮すると Scherrington の説の方が正しく思わ机る.

下腹神経の利尿筋に対する役割は, 骨盤神経のをれに 此較して, 甚だ劣勢であり排求反射に冷補助的な役割定 演ずるに過ざないこいわれているが，下腹神経の容積変 動に及改す效果空みても解るように単に膀胱よりの求心 性知覚の伝導路亡してでかりでなく, 積極的に内圧変化

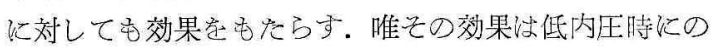

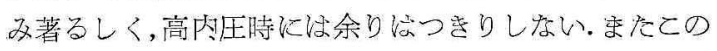
神経は利尿筋に対して抑制的に働くために, 利尿筋の収 縮である排尿反射といら点からみると積極的な役目结持 つていないで補助的な立場他る.膀胱のトーヌスの低 下が排尿反射に影響をむたえるとと流いう窎でもない.

下腹神経の末梢性運動路の作用を検する刺激実験に関 して，古来より数多くの研究業績をみるが，一般には利 尿筋认対しては弛緩作用学，内括約筋に対しては収縮作 用存するとの説 $\left(\right.$ Alpers $\left.^{2}\right)$ ) が支持されている. 利属 筋に対する反応形式は，単に弛緩作用を示すばかりでな く初期收縮に続いて同部の弛緩を件うとの意見が定説と なつている. (Wang and Harrison ${ }^{45)}$, Pratt and Malle- 
nby ${ }^{33)}$, Kuntz and Saccomano ${ }^{17)}$, Hegre and Ingersoll ${ }^{13) 14)}$ ) 著者の実験でも下腹神経の末梢端刺激により原則 的に核胱は弛緩的であつた。ただし一過性ではあるが 刺激初期に収縮的な効果がみられたことは，乙の神経中 にも膀胱收縮線維が多少含末れていることを意味するも のふもしれない.しかし平滑筋運動神経の作用は単純で なく，同じ神経線維でも収縮及び弛緩作用をひき起す可 能性があること注血管運動神経にも見られることで，一 概にこの事実から収縮線維の存在を結論すること㳊危俛 である．要するに下腹神経の末梢性運動路としての主な る作用は，利尿筋に対する抑制効果と考えられ諸家の成 績と一致する。

下腹神経の求心性伝導路汇関する報告は少なく，なか んずく下腹神経の切断中樞側に加えられた刺激効果につ いては, Sokownin ${ }^{42}$ の古典的実験を始めとして僅亦 二，三の記載を見るにすぎない．下腹神経一側切断後， 他側健在時に方の中樞端に加えられた刺激は, 当然下腸 間膜神経節を介するる反射としてその効果を期待すること ができる. Sokownin 洁猫で下腸間膜神経節の中樞との 結合を全部除いたのち, 左右いずれかの下腹神経の中樞 側の末梢端を刺激したところ, 反対側の下腹神経を下る 遠心性インパルスが出現すると共に膀胱の收縮するのを 観察した。後年 Langley and Anderson ${ }^{23}$ はこれを追試 し，てのよらな反応沈下腸間膜神経節にニコチンを作用 させると消失する点から，乙の反射現象を真の反射と区 別し, Pseudo-reflex と稱し，1つの神経細胞の軸索队付 で生ずる反射現象なので軸索反射と名付けた。きた Learmonth ${ }^{26)}$ は人間でてのふうな反射の存在を実証するた めに, 開腹手術時下腹神経切断中樞端の電気刺激圭行つ たが，何等の反応をも認めずとしている．しかるに著者 の実験では，両側下腹神経の存否のいかんに拘らずその 効果に有意の差が見られなかつた。また骨盤神経切断及 び下腸間膜神経節剔除後始めてその効果が消失する点よ り，著者は Sokownin の反射の存在を否定する. しふも 中樞端刺激効果が，下腹神経末梢端刺激時とほぼ同様に 容積变動の収縮と弛緩を以つて反応することは甚だ與味 深い.

下腹神経切断中樞端刺激が，下腸間膜神経節剔除後: の効果を消失することふら，中樞端に加えられた刺激放 下腸間膜神経節以上のレ心゙ルにまで到達していることな 明らかである.さらに耐側の下腹神経切断後もなおその 刺激効果が存続し, 骨盤神経切断によりその効果が消失

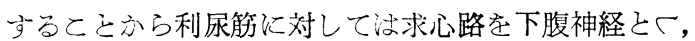

遠心路王骨盤神経已ずる反心推测し灷い。耐神経間代 介在与る反射弓が交感神経鎖，春剈後根神経節，脊骮棫

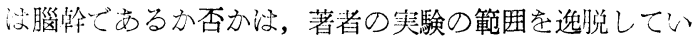
るので論議の対稱とはなり得ぬが，同時に記録した血 压, 呼吸等つ自律性反射より著者经次のごこく推論す る.

下腹神経の中樞との連絡路及び中樞の局在をいかなる 部位に求めるが極めて困難な問題である. 著者の実験 そ扢いて下腹神経の中樞端刺激が血圧, 呼吸飞著明な影 響をもたらしたとと注，てのふうな刺激が延骮レベルに まで到達し, それぞれ延䯣に打ける血管運動中樞, 呼吸 中樞と何等かの関連を有するととを暗示させる.中根 ${ }^{311}$ ，入沢 ${ }^{16)}$ は膀胱圧刺激の小腸に及注す影響学観察し, 膀胱一小腸反射の求心路, 遠心路を膀胱 $\rightarrow$ 下腹神経 $\rightarrow$ 延

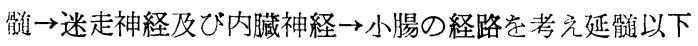
の反射弓の存在を否定している. Ranson and Billingsley ${ }^{36}$ 注猫を用い, 胸顝及び腰䯣の切截実験より血圧呼吸 を指標己して, 骨盤神経を刺激し求心性昇圧脊羟内線維 の通過部位を決定し昇圧性インパルスは春䯣後牦尖端部 定両側性に上行して, 腦の血管収縮中樞に至るとのべて いる. 銭場他 ${ }^{39}$ 快回盲部附近の小腸を生理的食塩水で刺 激し, 血圧呼吸を指標とする脊㭪道切截実験よりふっる刺 激注腸間膜神経及び内臟神経を求心性に上行し, 後根よ り春㕼に入り春䯣を第一次中樞とずるとのべている，副 島 ${ }^{38}$ 淰家象及び猫の坐骨神経中樞端刺激実験より血圧の 上界及び呼吸の興奮は, 該刺激が腦幹に局在する血管運 動中樞，呼吸中樞との間に密接な関連を有するためであ ると結論している。ささらに呂 ${ }^{48}$ 梳骨盤神経の中樞端電気 刺激により，脊䯣内反射弓の有無を調べたが，脊髄後索 及び側索を上行する経路を確認し，しかもそれらの線維 は延骮通の血管運動中樞, 呼吸中樞の近傍に終末すると し, さらに久留の稱する骨盤迷走神経及ご仙骮延䯑道路之 一致するものであると論及している。

以上のように骨盤内臓器の求心性刺激恃, 多少の異論 注あるにしても, 腦幹の血管運動中樞, 呼吸運動中樞之 の間に何等かの連絡路が存在するとと京認めざるを得な い.

延鹃におうる血管運動中樞及び呼吸運動中樞の局在に 関与る従来の研究業績を見ても著者の研究結果已矛盾与 るもの注とんどない. Wang and Harrison'45) 快血圧 上昇及び下降反応を呈する部位として延骮基底灰白質及 びこれに接する外側網様織の背側部，さらには外側及び

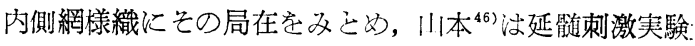


より孤束の周辺並びにてれに近接する網様織に存在する とし，武藤 ${ }^{35}$ 性束束核の吻側半及び尾側半に散在すると している。，一方呼吸中樞は，網様織中に可成り広汹な搪 がりを占めるが山本は Pitt, Magoun and Ranson ${ }^{34)}$ 等 の指適した延䯣内の呼吸中樞の挫がりが，血管運動中樞 に扮けると同様に述走神経背側核及び疑核を含む網様体 とはぼー致するとのべている。

久留等 ${ }^{18-22)}$ の系統的研究でも明らかなととく, 排尿

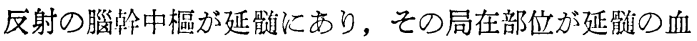
管運動中樞，呼吸中樞と平行あるいは重盢して存在する ことは，著者の実験に掞いて及られる下腹神経の求心性

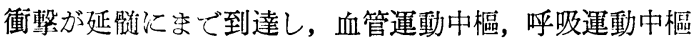
に影響を与える一方，排尿反射中樞を介する反射現象と して利尿筋の容積変動に变化をもたらしたものであ 弓.

従来膀胱よりの求心性インパルスに関する実駼的研究 快甚だ少なく, Talaat ${ }^{44)}$, Evans $^{8}$ ) 等 $2 ， 3$ の報告をみる にすぎない，とりわけ下腹神経の求心性インパルスは, 骨盤神経のそれとは対稱に膀胱運動々沙全く無関係に出 現し, 膀胱伸展時に順応性の極めてそしいインパルスが 得られることから, 恐らく膀胱よりの痛覚を伝達与るも のであらう之推測されているにすきない(44)

著者の実験で高内圧時に極めて順応性の乏しい discharge を, ついで過伸展を解除せしめた時速やかにこの discharge が消失することを確め得た．このdischarge が 痛覚を伝達するものであることに異論はないにしても， 膀胱内圧の上昇過程にあつてインパルスの頻度の增加を 来たすととは興味深い。

一般に膀胱支配神経，なかんずく骨盤神経の求心性イ ンパルスは膀胱収縮時にインパルスの増加を，弛䌅時に その減少を来たし ${ }^{15)}$ ，また膀胱内に液体を注入し徐々に 膀胱伸展を来さしめ内圧の上昇を起さしめると，その頻 度が増加するとされ，さらには急速に膀胱内一注入を行 い膀胱過伸展を苍起させると，乙のような伸展過程を避 けようとして急激な神経活動の発現を観察し得ると報告 されている8).

著者の実験で得られた下腹神経求心性インパルスは前 述の過伸展時の discharge の他に膀胱内圧の上昇之関連 して頻度の増加をみ，また念速に膀胱伸展を起さしめた 場合内圧上昇と期を一にして一過性の discharge 群が発 現することは，従来報告されている下腹神経の求心性イ ンパルスのパターンと趣を異にしている。これは明らか に蓇盤神経のパターンと類似している。また Iggo $^{15)}$ が
骨盤神経叢より得たものとも類似している点から下腹神 経滛骨盤神経と同じく tension-receptor の存在を推測 せしめる.さらに下腹神経の切断末梢端刺激とより, 利 尿筇の一過性収縮と弛緩とを惹起せしめ, ついでかかる 反応に対応して出現与る下腹神経の求心性インパルスを 他側の下腹神経末梢端より尊出し検討したが，刺激と同 特に出現する burst は内压の絶対值ではなく, 上昇変化 に伴つて 2 相的比起り, 弛緩相では減退或は消失する.

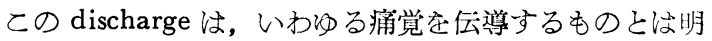
らかに異なり, 内圧の相的変動々の間汇相関性を認める 点などを考磨すると，恐らくは前述した tension-receptor 心らの線維より得られたものと考えるととが出来よう.

\section{5. 結 語}

下腹神経の膀胱容積変動に及洔す影響を，下腹神経切 断実験並びに刺激実験より検討すると共に，下腹神経の 求心性インパルスに関する分析を行い次のどとき結果を 得交.

1）膀胱支配神経無処置群に妨つて㧒，その律動的容 積変動の周期梳膀胱内圧上昇飞伴つて短縮する。一方下 腹神経切断群では，膀胱内圧 $20 \mathrm{~mm} H \mathrm{H}$ 以下の低队圧時には 無処置群に比較して周期は延長し，30 mm Hg以上の内圧で は両者の間には湶とんど有意の差がみとめられない。こ れは下腹神経が利尿筋に対して抑制作用を有するととを 示し，しかもその作用効果は低内圧時に著るしい。

2）下腹神経切断末梢端刺激忟，利尿筋の一過性收縮 とそれに引繶く弛緩効果を示した。

3）下腹神経切断中樞端刺激は，末梢端刺激と同様泣 利尿筋の一過性収縮とそれに引続く弛綏効果を示した が, 下腹神経一側切断及び両側切断でもその刺激効果に 著変なく, 下腸間膜神経節剔除後及び両側骨盤神経切断 後消失した。同時に記録した自律性反射は，末梢端刺激 では何等の効果も認められなかつたが, 中樞端刺激では 全例に血圧の上昇と呼吸気量の増大を惹起した。

4）上記の刺激効果より，下腹神経の中樞端刺激によ る下腸間膜神経節を介する軸索反射, いわゆるSokownin の反射の存在汪極めて疑はしい．また上記の自律性反射 の存在より推測すると, 下腹神経中樞端に加えられた刺 激によつて惹き起される膀胱容積変動の反射中樞は, 延 噵の排尿反射中樞と密接な関連を有するととを想定させ る.

5）膀胱内圧変動に起因する下腹神経の求心性インパ ルスは次の 2 群に分類される。

i）膀胱過伸展時に出現し，順応性にそしく膀胱ょり 
の疼痛の伝導路と推定され，排尿已関係のないもの.

ii）膀胱の伸展過程に执いて出現し, 内圧変動々相関 性を有するもの.

稿を終るに当り，終始慜篤なる御指導と御校閲を賜つ た恩師原田彰教授並びに第 1 生理学教室畠山一平教授に 深甚なる謝意を表します。

（本論交の要旨は第 282 回日本泌尿器科学会東京地方 会, 第52回, 第53回日本泌尿器科学会総会にて 発表し た。また本論交は横浜市立大学大学院学位論文であるこ とを附記する。）

\section{交献}

1) Adrian, E.D. and Bronk, D.W.: J. Physiol., 66, 81, 1928.

2) Alpers, B.J.: Clinical Neurology, 2 nd Ed. 1950.

3) Barrington, F.J.F.: Quart. J. Exp. Physiol., 8, 33, 1914.

4) Barrington, F.J.F.: Quart. J. Exp. Physiol., 9, 261, 1915.

5) Barrington, F.J.F.: Brain, 54, 177, 1931.

6) Courtade, D. and Guyon, J.F.: Arch. de Physiol., 8, 622, 1933.

7) Elliott, T.R.: J. Physiol., 35, 367, 1907.

8) Evans, J.P.: J. Physiol., 86, 396, 1936.

9) Edmunds, C.W. and Roth, G.B.: J. Pharm. a. Exp. Therap., 15, 189, 1920.

10）福田弘：日本外科学会雑誌， 57, 1481， 1956.

11) Fukuyama, U.: Fukushima J. med. sci., 1, $117,1954$.

12) Gaskell, W.H.: J. Physiol., 7,1886.

13) Hegre, E.S. and Ingersoll, E.H.: J. Urol., 61, 1037, 1949.

14) Hegre, E.S. and Ingersoll, E.H.: J. Urol., 72, 1781, 1954.

15) Iggo, A.: J. Physiol., 128, 593, 1955.

16）入沢優氏：日本生理誌，17, 420, 1955.

17) Kuntz, A. and Saccomano: J. Urol., 51 535, 1944.

18) Kuru, M.: Jap. J. Physiol., 1, 240,1951.

19) 久留勝: 最新医学, 10, 1, 1955.

20) Kuru, M.: J. Comp. Neurol., 104, 207, 1956.

21）久留勝：日本臨床，15，466,1957.

22) Kuru, M., Kurati, T. and Koyama, Y.: J.
Comp. Neurol., 113, 365, 1959.

23) Langley, J.N. and Anderson, H.K.: J. Physiol., 16, 416, 1894.

24) Langworthy, O.R., Reeves, D.L. and Tauber, E.S.: Brain, 57, 266, 1934.

25) Langworthy, O.R., Kolb, L.C. and Lewis, L. G.: Physiology of micturition, Williams and Wilkins Co., 1940.

26) Learmonth, J.R.: Brain, 54, 147, 1931.

27) MacDonald, A.D. and McCrea, E.D.: Quart. J. Exp. Physiol., 20, 379, 1930.

28) McCaughan, L.N.: Missouri State Med. Assoc., 34, 379, 1937.

29) Mosso, M.A. and Pellacani, P.: Arch. Ital. de Biol., 1, 291, 1882.

30）中野修道：日泌尿会誌， $54 ， 858,1963$.

31）中根公正他：日本生理誌, 16, 287, 1954.

32) Dennig, H.: “Die Innervation der Harnblase ”, 8)上り引用.

33) Mellanby, J. and Pratt, C.L.G.: Pro. Roy. Soc., 127, 307, 1939.

34) Pitts, R.F., Magoun, H.W. and Ranson, S. W.: Am. J. Physiol., 126, 673, 1939.

35）武藤邦雄: 十全医学雑誌, 55, 165, 1953.

36) Ranson, S.W. and Billingley, P.R.: Am. J. Physiol., 41, 16, 1916.

37) Scabadasch, A.: Zeitschrift f. Anat. u. Entwicklungsgeschichte, 86, 730, 1928.

38) 副島寿太郎 : 医学研究, 25, 10, 1955.

39）銭場武诚他：日本生理誌， 15，43，1953.

40) Scherrington, C.S.: J. Physiol., 8, 621, 1892.

41）坂川邦有：日泌尿会誌， 51， 1091，1960.

42) Sokownin, S.: Pflug. Arch. ges. Physiol., $8,600,1874$.

43) Stewart, J.C.: Quart. J. Exp. Physiol., 27, 193, 1938.

44) Talaat, M.: J. Physiol., 89, 1,1937.

45) Wang, S. and Harrison, F.: Am. J. Physiol., 125, 301, 1939.

46) 山本信二郎：十全医学会雑誌, 54, 122, 1952.

47) Ruch, T.C. and Fulton, J.F.: Medical Physiology and Biophysics, 18th Ed. W.B. Saunders Co., 1960.

48）呂震義：大阪医学会雑誌，11，1895，1959. （昭和 41 年 1 月 7 日受付，特別掲載） 